\title{
Features of Digital Education Mentors' Innovations
}

Elena E. Merzon ${ }^{1, a}$, Irene Sibgatullina-Denis ${ }^{1,2, b}$, Alica Vančová $^{3, c}$, Snezhana G. Ushakova ${ }^{1, d}$

'Yelabuga Institute (Branch) of FSBEI of HE "Kazan (Volga Region) Federal University",

Yelabuga, Russian Federetion.

${ }^{2}$ Institute for Intellectual Integrations,

Vienna, Austria.

${ }^{3}$ Institute of Special Education Studies of Comenius University,

Bratislava, Slovakia.

a (ID ORCID: https://orcid.org/0000-0001-7708-2946, e-mail: elena.merzon@kpfu.ru

biD ORCID: https://orcid.org/0000-0001-5149-6139, e-mail: office@rbs-ifie.at

ORCID: https://orcid.org/0000-0001-6885-4166, e-mail: vancova@fedu.uniba.sk

diD ORCID: https://orcid.org/0000-0001-5263-584X

Abstract: The strategy for the development of international education 20.30 stimulates the study of the issues in the implementation of digital education around the world. The article discusses current applied and practical issues of digital education that educational management specialists came across.

Materials and Methods. The authors research management of digital education through mentoring, mentoring pedagogy and mentoring innovations in traditional learning environments and during the time of crisis. The study presents an applied comparative analysis of the questions of targeted intensities, digital footprint, the SELFIE portal usage features, objectives and technologies for training digital mentors.

Results. The research findings show an underutilisation of informal education ideas and technologies in the in the process of training digital mentors. The predominance and stable efficiency in the use of informal education takes place at leading European universities. From the standpoint of a humanistic view, exactly informal education is able to balance and regulate the need for knowledge of technologies of an innovative digital economy and its own individual resource for preserving itself, basic life values, and form digital education informal mentors.

Discussion and Conclusion. Why does the mentor of a targeted digital educational intensive have a psychological advantage? Can everyone become a mentor in network communication for the rest, and what are the digital education mentor's competencies? What contribution can everyone make to the training of the others? The discussion these issues in the context of management strategies for the development of international education, and the implementation of the European plan for the quality of digital education will be useful to for heads of educational organizations, departments of continuing professional education and academic mobility of educators.

Keywords: mentoring innovations, digital competence, the diversity of the digital footprint, critical thinking, personal significance, mentor of digital education.

For citation: Merzon E.E., Sibgatullina-Denis I., Vančová A., \& Ushakova S.G. (2021). Features of Digital Education Mentors' Innovations. Razvitie obrazovaniya = Development of education, 4(2), 20-25. DOI 10.31483/r-98810.

\section{Особенности инноваций в наставничестве в области цифрового образования}

\author{
Мерзон Е.Е.1,a Сибгатуллина-Денис И. ${ }^{1,2, b}$, Ванчова А. ${ }^{3, c}$, Ушакова С.Г., \\ 1Елабужский институт (филиал) ФГАОУ ВО «Казанский (Приволжский) федеральный университет», \\ Елабуга, Российская Федерация. \\ ${ }^{2}$ Институт интеллектуальных интеграций, \\ Вена, Австрия. \\ Зинститут специальных педагогических исследований Университета имени Я. А. Коменского, \\ Братислава, Словакия. \\ D ORCID: https://orcid.org/0000-0001-7708-2946, e-mail: elena.merzon@kpfu.ru \\ b ID ORCID: https://orcid.org/0000-0001-5149-6139, e-mail: office@rbs-ifie.at \\ ORCID: https://orcid.org/0000-0001-6885-4166, e-mail: vancova@fedu.uniba.sk \\ diD ORCID: https://orcid.org/0000-0001-5263-584X
}

Резюме: Стратегия развития международного образования 20.30 стимулирует процесс изучения вопросов внедрения цифрового образования во всем мире. В статье рассматриваются актуальные прикладные и практические вопросы цифрового образования, с которыми столкнулись специалисты управления образования.

Материалы и методы. Авторы исследуют управление цифровым образованием через наставничество, педагогическое наставничество и инновации в наставничестве в традиционной учебной среде и в период кризиса. В исследовании представлен прикладной сравнительный анализ вопросов целевых ориентиров, цифрового отпечатка, особенностей использования портала SELFIE, целей и технологий обучения наставников в области цифрового образования.

Результаты исследования свидетельствуют о недостаточном использовании идей и технологий неформального образования в процессе подготовки наставников цифрового обучения. В ведущих европейских университетах наблюдается преимущество и стабильная эфффективность использования неформального образования. С точки зрения гуманистического взгляда, именно неформальное образование способно сбалансировать и урегулировать потребность в знаниях о технологиях в сфере инновационной цифровой экономики и ее собственном индивидуальном ресурсе для самосохранения, базовых жизненных ценностях, а также сформировать наставников в области неформального цифрового образования.

Обсуждение и заключение. Почему наставник целевого цифрового образовательного ориентира имеет психологическое преимущество? Может ли каждый стать наставником в сетевом общении для остальных, и каковы ком- 
петенции наставника в области цифрового образования? Какой вклад каждый может внести в обучение других? Обсуждение этих вопросов в контексте стратегий управления развитием международного образования и реализации Европейского плана по качеству цифрового образования будет полезно руководителям образовательных организаций, отделов непрерывного профессионального образования и академической мобильности педагогов.

Ключевые слова: инновации в наставничестве, цифровая компетентность, разнообразие цифрового следа, критическое мышление, личностная значимость, наставник в области цифрового образования.

Для цитирования: Мерзон Е.Е. Особенности инноваций в наставничестве в области цифрового образования / Е.Е. Мерзон, И. Сибгатуллина-Денис, А. Ванчова [и др.] // Развитие образования. - 2021. - T. 4, №2 - С. 20-25. DOІ $10.31483 / r-98810$.

\title{
Цифра вӗренӗвӗн талккӑшӗнче усӑ куракан ӑс парса ертсе пыру нновацийӗн уйрӑмлӑхӗсем
}

\author{
Мерзон Е.Е., , Сибгатуллина-Денис И.1,2,b Ванчова А. ${ }^{3, c}$, Ушакова С.Г., \\ ${ }^{1}$ Елабужский институт (филиал) ФГАОУ ВО «Казанский (Приволжский) федеральный университет», \\ Елабуга, Российская Федерация. \\ 2'Институт интеллектуальных интеграций, \\ Вена, Австрия. \\ зИнститут специальных педагогических исследований Университета имени Я. А. Коменского, \\ Братислава, Словакия. \\ a iD ORCID: https://orcid.org/0000-0001-7708-2946, e-mail: elena.merzon@kpfu.ru \\ ORCID: https://orcid.org/0000-0001-5149-6139, e-mail: office@rbs-ifie.at \\ ORCID: https://orcid.org/0000-0001-6885-4166, e-mail: vancova@fedu.uniba.sk \\ diD ORCID: https://orcid.org/0000-0001-5263-584X
}

Аннотаци: Тӗнче вӗренӳ аталанӑвӗн 20.30 стратегийӗн цифра вӗренӗвне тӗнче шайӗнче вӑя епле кӗртсе пынине тӗпчеме хавха парать. Статьяра цифра вӗренӗвне ертсе пырас енӗпе ӗс̧лекен специалистсем тӗл пулакан куллен кирлӗ тата практикӑпа с̧ыхӑннӑ пӗлтерӗшлӗ ыйтӑвӗсене пӑхса тухнӑ.

Материал тата меслетсем. Авторсем цифра вӗренӗвне ӑс парса ертсе пынине, педагогика с̧ине таяннӑ ертсе пыру тата ӑс парура вӑй илекен инноваци кризиса кӗнӗ вӗренӳ талккӑшӗнче епле улшӑннине тӗпчес̧с̧ӗ. Тӗпчевре тӗллев те̌шмӗртӗвӗн ыйтӑве̌сене пурнӑс̧па с̧ыхӑнтарса тишкернӗ, цифра йӗрне, SELFIE программӑпа усӑ курнин уйрӑмлӑхӗсене, цифра вӗренӗвӗ валли ӑс парса ертсе пыру специалисчӗсене хатӗрлессин тӗллевӗсемпе технологийӗсене илсе кӑтартнӑ.

Тӗпчев результачӗсем ӑс парса ертсе пырус̧ӑсене хатӗрленӗ чухне формал мар вӗренӗвӗн идейисемпе тата технологийӗсемпе туллин усӑ курманнине с̧ирегплетес̧сеӗ. Европӑн малта пыракан университечӗсенче формал мар ве̌ренӳпе анлӑ усӑ курас тата унран тухӑс̧лӑх тӑтӑш илес туртӑм пур. Гуманизм енчен илес пулсан - иннновациллӗ цифра экономикипе пе̌лӱ кирлӗле̌хне, унӑн хӑйне хӑй упраса хӑвараслӑхне шӑп та лӑп формал мар вӗренӳ йӗркелесе, шайлаштарса пырать тата фрормал мар цифра вӗренӗвӗ валли ӑс парса ертсе пыракансене хатӗрлеме май парать.

Сӱmсе яву тата пӗтӗмлетӱ. Цифра енӗпе теллевлӗ вӗренӳре ăс парса ертсе пырус̧ӑ психологи енчен мӗншӗн пахарах? Сетьре хутшӑнакансемшӗн кашни с̧ын ӑс парус̧ӑ пулма пултарать-и? С̧авӑн пекех, ăc парус̧ӑн компетенцийӗ мӗнлерех пулмалла? С̧ын ыттисене вӗрентме мӗн таран пулӑшма пултарать? Асӑннӑ ыйтусене тӗнче вӗренӗвне йӗркелес стратегийӗн шайӗнче тата Цифра вӗренӗвӗн пахалӑхне ӳстерес енӗпе Европа планне пурнӑс̧лас енчен пӑхса тухни вӗренӳ организацийӗсен, профессие алла илессине тӑтӑш вӗренӯ мелӗпе йӗркелекен пайсен ертӳс̧исене усӑллӑ пулать тата педагогсене вӗренӳ енчен ирӗклӗ тӑвать.

тӗп сӑмахсем: ăс парса ертсе пыру с̧ӗнӗлӗхӗ, цифра компетенцилӗхӗ, цифра йӗрӗн расналӑхӗ, критикӑллӑ шухӑшлав, с̧ынлӑх пӗлтерӗшӗ, цифра вӗренӗвӗн талккӑшӗнче ӗс̧лекен ертӳс̧ӗ.

Цитатӑлама: Мерзон Е.Е. Цифра вӗренӗвӗн талккӑшӗнче усӑ куракан ӑс парса ертсе пыру нновацийӗн уйрӑмлӑхе̌сем / Е.Е. Мерзон, И. Сибгатуллина-Денис, А. Ванчова [и др.] // Вӗренў аталанӑве̌. - 2021. - Т. 4, №2. C. 20-25. DOI:10.31483/r-98810.

\section{Risks and Benefits of Digital Education Mentors}

Many leading universities in the world interact with technology parks and are interested in creating special platforms for mentors in various areas and specialties that can be used in everyday practice and during crisis events [3]. World technology parks today offer targeted mentor intensives, monitor the development of mentor competencies and the informal network of their interaction. The necessary condition for such targeted intensive programmes is the uniqueness of technical capabilities and equipment for the special format of university teaching tasks and the situation in which training is organized. The idea of intensives is associated with the formation and development of digital competencies and skills of network communication participants under the mentor's observation and in interaction with the mentor in situations of different formats. Intensive participants, regardless of age, but depending on the level of digital competencies, master knowledge by means of end-to-end digital technologies. Such training practically does not have psychological risks, on the contrary, it has a psychological advantage in the form of a diverse digital footprint, the ability of mentors and learners to complement each other and form a consortium of experts and mentors studying subject opportunities and innovations in digital education in the framework of common social educational interactions and crisis events [4].

The authors of the article are disturbed by the fact that today there is a shortage of highly qualified mentors around the world. That is, mentors who have a perfect command of some kind of mentor digital technology and at the same time possess strategic systemic critical thinking. Mentors who understand how all these technological projects can be interconnected in the future or, for example, operate in crisis events, such as those faced by European school and university teachers in the context of the necessary self-isolation in 
March 2020. It is important that even the past intensives could not predict the full completeness of the fact that everyone can become a mentor for the others; everyone can contribute to the teaching of others. This complex formula is like an equation with several unknowns, at least two. One unknown quantity is the reliability of the mentor's qualifications for current digital learning tasks; the other is the type of conditions and events in which this qualification can be fully manifested. The intensive, which took place in the Russian Federation on Island Russky in July 2018, was the first experiment in this field that was at the same time a training session. The intensive programme included the creation of a «digital footprint». Every participant received a biofeedback bracelet. The participants' heart rate was measured for 11 days, and on the basis of these observations it was determined how the participants' concentration and perception changed, to what extent the participant was involved in the process and was able to, or could no longer perceive, new information. Eye movement and cognitive load were «monitored». As a result, the collected data allowed developing the primary technology to quantify mentors' resource state at the time of training [11].

Superjob President Alexei Zakharov notes the fact that teams of mentors and world-class experts in the digital space will sooner or later be available for communication with anyone who can search the Internet. Undoubtedly, network communication on the Internet will never replace live communication with a mentor, but it will be able to «build» the paths of joining international teams to implement technological projects for different purposes and attract mentors from different parts of the world. The authors of the article tend to call such a strategy " Mentor +". Actually, to some extent, this is already happening on the network. However, we also note the fact that so far in international education, the "Mentor +" communication is unsystematic and even chaotic. Undoubtedly, search and work in such international teams will reduce the time for preparing digital educational projects, but it will create difficulties for the subjects of education in trusting each other and being responsible to each other. In our opinion, this is good. Though it is true, that such a psychological risk should be foreseen. It should also be noted that in the context of the digital environment development in the school - university dyad, it is necessary to be able not only to learn, but also to expand the mentor's functionality. Such a trend has appeared in the world of digital education quite recently. Mentoring in the digital age is of a paramount importance, for practical skills are transferred here. It is worth while repeating that mentoring distinctive feature is that everyone can become a mentor for anyone; everyone can contribute to training other people depending on the situation and the project event.

At first glance, it is still difficult for educational managers to clearly define the hierarchy of mentor competencies in the digital uncertainty of the new world order, or rather, in the new classification of the future: predicted, projected, and desired [9]. Nevertheless, the authors venture to list what will change in this type of mentoring and what is necessary for it: a mentor is a source of competencies for those who master and develop these competencies; a mentor is the one who has designed educational ideas and plans for their implementation; recruiting a team under a mentor's supervision and a «digital footprint» of the «Mentor +" format; the main condition is motivation to be a mentor; and certainly, availability of a suitable project and conditions for its implementation. We must note the mentor's role in creating interfaces that allow determining what is most effective for every learner in different conditions. The enrichment of learning content is also the responsibility of mentors who are more flexible than anyone else in regulating the vector of orientation to the new subjects in digital learning and significant in personal growth.

\section{The critical mass of psychological readjustment}

It should be accepted that the digital learning mentor «here and now» is in the uncertain present. The transition from the present to the future, especially in its three vectors, which the authors wrote about above (predicted future, projected future and desired future), is all the more difficult, though inevitable for the living people. We must add here the uncertainty of crisis events that can occur from nowhere and disappear into nowhere. Evidently, this is a lengthy process. It can be gaining a critical mass for a long time, but when this mass has been gained, further changes occur very quickly. Moreover, the question is not only in the readiness of mentoring technologies in digital learning, but also in regulation and psychological «reconfiguration», here we draw attention to the term «reconfiguration». Over-satisfied with the monotonous products of mass digital production, the world is looking for new sensations. People no longer want to be like everyone else; everyone seeks to stand out with their individuality, ceases to be a passive consumer of digital space and becomes an active participant in everything - seeking self-realization in work, in leisure, in study, and in creativity. Impressions and sensations at present (!) are the main commodity and the main capital today. This is true for those who teach and for those who study. This is how the economy of impressions develops in the digital world of robotics. Turning to the idea of informal education [5] that is considered in the context of a person's life path and life events, where universities are not only university classrooms and libraries, but a multiplicity of digital and other sources directly related to self-knowledge, the search for significance and reflection, we will express a very controversial thought. From the standpoint of a humanistic view, informal education is able to balance and regulate the need for knowledge of technologies of an innovative digital economy and its own individual resource for preserving itself, basic life values, and form digital education informal mentors. By informal education, the authors understand education outside any form, directed deep within itself, its own life significance, professional training and personal development values, an embodiment of self-knowledge, devoid of strict regulation, spatial and temporal boundaries $[10 ; 14]$.

It should be noted that the work on the development of the theory and practice of media education in the digital economy is among the priorities of the departments of 
media education in many pedagogical universities and higher pedagogical schools of the world. However, if the mentor fails to find a balance between the «digit» and the «character of his I», it will be difficult for him to perceive digital reality as such and even more so to shape it in the class, not to mention the individual resource of the teacher for mentoring in the «everyone for everybody» format. The critical mass of «reconfiguration» of mentors is thus expressed in the simultaneous change and adoption of new professional actions and, what is not unimportant, personal significance $[12 ; 13 ; 14]$.

\section{The idea of the European portal SELFIE}

The European Commission has introduced a new tool that will help all schools in the EU, as well as in Russia, Georgia and Serbia, to assess the degree to which they use digital technologies in teaching and learning. In the EU, 76.7 million learners and teachers from 250 thousand schools will be able to use the SELFIE portal on a voluntary basis [7]. Reference: the abbreviation SELFIE stands for «selfassessment of the effectiveness of education by expanding the use of innovative educational technologies»».

At the time of launch, the portal was available in $24 \mathrm{EU}$ languages, and later other languages were added. Today the portal is available in 30 languages. Any interested school (primary, secondary, and secondary vocational education institutions) can register on the SELFIE portal and conduct a self-assessment. At the SELFIE portal launch event in Warsaw, Tibor Navračić, a member of the European Commission for Education, Culture, Youth Policy and Sports, said that «SELFIE can help you to use technical tools in teaching and learning purposefully and comprehensively. Gathering feedback, it can play an important role in adapting the European education system to the digital age. I am sure that the SELFIE portal will help us to improve the digital skills of Europeans. This is fundamentally important if we want all of them to be able to use the opportunities of a globalized, knowledge-based economy. And it is necessary to build a society in which people are confident, demanding users of new technologies, not their passive consumers». The SELFIE portal is one of 11 initiatives of the Digital Education Action Plan launched by the European Commission in January 2019. The action plan aims to develop digital skills in Europe and to support the innovative use of digital technologies in teaching and learning [1].

How does the SELFIE portal work? After gaining access to the SELFIE portal, users fill out a questionnaire, noting the degree of their agreement with a number of brief questions in order to assess the scale of use of the portal data in the process of digital learning and, or digital teaching. The tool is modular, and its users can choose from a number of additional questions, as well as add up to eight individual questions depending on their own interests. Commenting on questions takes from 20 to 30 minutes. On the results of the survey, a report is generated, on the basis of which a team of mentors can discuss measures to improve the use of digital technologies in training. Such measures may include special intensive training or Internet security initiatives. All answers on the SELFIE portal are anonymous, the portal does not collect personal data, and the information received is not used to compile system ratings.

Currently, mentors have announced the development of the portal. The first SELFIE conference with the support of the Ministry of Education of Spain was held on April 4-5, 2019 in Madrid. The event brought together representatives of European project participants whose experience and feedback will be used for further improvement. To expand the use of digital technology by innovative mentors, the European Commission is developing methodological materials based on SELFIE self-assessment. The Commission is also exploring how the SELFIE portal can interact with existing communities, in particular with the eTwinning portal [2], which, with the support of the Erasmus + program 20.30, has become the world's largest community of digital education mentors.

\section{Reference Information}

The European Commission works on the SELFIE portal in partnership with national ministries of education and a group of European experts in digital learning. Partner organizations include the European Foundation for Education, the European Center for the Development of Vocational Training, and the UNESCO Institute for Information Technologies in Education. Last year, a pilot version of the portal was tested in 14 countries. According to the results of the project, 67 thousand proposals were received to simplify and improve this tool; they have been taken into account in the portal current version. Reference information on the SELFIE portal in English is available on the website of the European Commission [6]. There is also a SELFIE portal on Twitter: \#SELFIE_EU [8].

\section{Conclusion}

Mentoring in the digital age is an important component of digital education. Discussions on the management of digital education through mentoring, mentoring pedagogy and mentoring innovations in traditional learning environments and during the time of crisis are not yet complete and need to be continued to find answers. Targeted intensives, the «digital footprint» and the SELFIE portal created in the EU reflect the reality of the constructive and deconstructive aspects of digital education development. The mentor of the targeted digital educational intensive has a psychological advantage, because he can become a mentor in network communication for other people by improving his own competencies through getting simultaneous training from others. Strategies for managing international education development, the implementation of the European plan for the quality of digital education set a breakthrough vector in building common value systems for educational choice in digital environment and introducing changes that will turn the fourth industrial revolution into new opportunities for everyone. 


\section{Список литературы}

1. Digital Education Action Plan // ec.europa. - 2018. URL: https://ec.europa.eu/education/education-in-the-eu/ digital-education-action-plan_en

2. eTwinning - Portal of the school community in Europe // etwinning. - 2019. URL: https://www.etwinning.net/en/ pub/index.htm

3. Merzon Elena E., Riabov Oscar R. Resonant mechanisms of territory branding in the DUDR System: Smart University - Smart Region. No: Proceedings of the III International Scientific conference on Visual Anthropology - 2019. City-University: Living Space and Visual Environment, August 28-30, 2019, Veliky Novgorod. Veliky Novgorod, 2020, 430. $-438 \mathrm{p}$.

4. Merzon E.E., Riabov O.R. The ambiguity of digital education issues. No: Psychology in Education, 2019, vol. 1, no. 1 , pp. 39-43.

5. Modern Workplace. The difference between formal and informal learning. URL: https://www. modernworkplacelearning.com/cild/mwl/the-difference-between-formal-and-informal-learning/

6. SELFIE - Reference information on the portal in // ec.europa. - 2019. URL: https://ec.europa.eu/education/sites/ education/files/selfie-info-factsheet_en.pdf

7. SELFIE // ec.europa. - 2019. URL: https://ec.europa.eu/education/schools-go-digital

8. SELFIE on «Twitter». URL: https://twitter.com/hashtag/SELFIE_EU?src=hash

9. Shulman E. The country of «understandable tomorrow»: cultural tools of political science // School of Anthropology of the Future, RANESS, December 13, 2019. URL: http://ppr19.ru/prognoziruemoe-proektiruemoe-zhelaemoebudushhee-_shulman.htm /Russian

10. Sibgatullina I.F. Informal education and benchmarking in the system of learning cities / I.F. Sibgatullina, L.N. Nugumanova // Visual Anthropology - 2019. City-University: Living Space and Visual Environment: Proceedings of the III International Scientific Conference, August 28-30, 2019, Veliky Novgorod / edited by S. S. Avanesov, E. I. Speshilova. Veliky Novgorod: Novgorod State University named after Yaroslav the Wise, 2020. - pp. 489-499.

11. Sibgatullina I.F. The running of time in digital education / I.F. Sibgatullina, O.R. Ryabov; scientific ed. D.M. Shakirova. Kazan: GAOU DPO IRO RT, 2019. - Issue 4. - 76 p.

12. Сибгатуллина И.Ф. Цифровое наставничество в системе бенчмаркинга востребованных форматов образования и управления талантами / И.Ф. Сибгатуллина, А. Ванчова, И.Е. Нургатина, Е.В. Павлухина // Вестник СВФУ. - Якутск: Государственное автономное образовательное учреждение высшего образования «Северо-Восточный федеральный университет имени М. К. Аммосова», 2021. - 1(21). - С.15-23 [Электронный ресурс]. - Peжим доступа: http://ppfsvfu.ru/wp-content/uploads/2021/03/\%D0\%9F\%D0\%9F\%D0\%A4-1-2021.pdf

13. Sibgatullina I., Riabov O., Merzon E., Vančová A., Sulovská M. Digital perspectives of benchmarking education in conditions of uncertainty. Paedagogica specialis 34: zborník vedeckých príspevkov Pedagogickej fakulty Univerzity Komenského v Bratislave. -: 1. vyd. ISBN 978-80-223-5049-5. - Bratislava: Univerzita Komenského v Bratislave, 2020. S. 261-271. URL: http://alis.uniba.sk:9909/lib/item?id=chamo:373043

14. Sibgatullina-Denis I., Riabov O.R., Merzon E.E., Vančová A. Descriptive Analysis of Benchmarking in Respect to SMART/UNI-Q Systems' Intellectual Integrations within the European Higher Education Area. Integratsiya obrazovaniya = Integration of Education. - 2020. - 24(4). - p. 532-551. DOI: 10.15507/1991-9468.101.024.202004.532-551

\section{References:}

1. (2018) Digital Education Action Plan. ec.europa. Retrieved from URL: https://ec.europa.eu/education/educationin-the-eu/digital-education-action-plan_en

2. (2019). eTwinning - Portal of the school community in Europe. etwinning. Retrieved from URL: https://www. etwinning.net/en/pub/index.htm

3. Elena, E., \& Oscar, R. (2020). Merzon, Riabov Resonant mechanisms of territory branding in the DUDR System: Smart University. Veliky Novgorod.

4. Merzon, E.E., \& Riabov, O.R. The ambiguity of digital education issues. No: Psychology in Education, 2019, vol. 1 , no. 1 , pp. 39-43.

5. Modern Workplace. The difference between formal and informal learning. Retrieved from URL: https://www. modernworkplacelearning.com/cild/mwl/the-difference-between-formal-and-informal-learning/

6. (2019) SELFIE - Reference information on the portal in // ec.europa. Retrieved from URL: https: https://ec.europa. eu/education/sites/education/files/selfie-info-factsheet_en.pdf

7. (2019) SELFIE. ec.europa. Retrieved from URL: https://ec.europa.eu/education/schools-go-digital

8. SELFIE on "Twitter". Retrieved from URL: https://twitter.com/hashtag/SELFIE_EU?src=hash

9. Shulman, E. (2019). The country of "understandable tomorrow": cultural tools of political science. School of Anthropology of the Future, RANESS. December 13. Retrieved from URL: http://ppr19.ru/prognoziruemoeproektiruemoe-zhelaemoe-budushhee-_-shulman.htm

10. Sibgatullina, I.F., \& Nugumanova, L.N. (2019). Informal education and benchmarking in the system of learning cities. Visual Anthropology, 489. Yaroslav the Wise. 
11. Sibgatullina, I.F., Shakirova, D.M., Ryabov O.R. (2019). The running of time in digital education., 4.; Kazan: GAOU DPO IRO RT.

12. Sibgatullina, I.F., Vanchova, A., Nurgatina, I.E., \& Pavlukhina, E.V. (2021). Tsifrovoe nastavnichestvo v sisteme benchmarkinga vostrebovannykh formatov obrazovaniia i upravleniia talantami. Vestnik SVFU, Vostochnyi federal'nyi universitet imeni M.K. Ammosova". Retrieved from http://ppfsvfu.ru/wp-content/uploads/2021/03/\%D0\%9F\%D0\%9F\% D0\%A4-1-2021.pdf

13. Sibgatullina, I., Riabov, O., Merzon, E., Vancova, A., \& Sulovska, M. (2020). Digital perspectives of benchmarking education in conditions of uncertainty. Paedagogica specialis 34: zbornik vedeckych prispevkov Pedagogickej fakulty Univerzity Komenskeho v Bratislave. - 1. vyd., 261. Bratislava: Univerzita Komenskeho v Bratislave. Retrieved from URL: http://alis.uniba.sk

14. Sibgatullina-Denis, I., Riabov, O.R., Merzon, E.E., \& Vancova, A. Descriptive Analysis of Benchmarking in Respect to SMART. doi:10.15507/1991-9468.101.024.202004.532-551

Information about the authors

Elena E. Merzon - candidate of pedagogical sciences, associate professor, director of Yelabuga Institute (Branch) of FSBEI of HE "Kazan (Volga Region) Federal University",

Yelabuga, Russian Federation. Irene Sibgatullina-Denis doctor of psychological sciences, professor, director of the Institute for Intellectual Integrations,

Vienna, Austria;

affiliated professor of Yelabuga Institute (Branch) of FSBEI of HE

"Kazan (Volga Region) Federal University",

Yelabuga, Russian Federation. Alica Vančová - doctor of psychological sciences, professor, director of the Institute of Special Education Studies of Comenius University, Bratislava, Slovakia. Snezhana G. Ushakova - master's degree student of Yelabuga Institute (Branch) of FSBEI of HE "Kazan (Volga Region) Federal University", Yelabuga, Russian Federation.
Информация об авторах

Мерзон Елена Ефимовна - канд. пед. наук, доцент, директор,

Елабужский институт ФГАОУ ВО «Казанский (Приволжский) федеральный университет»,

Елабуга, Российская Федерация.

Сибгатуллина-Денис Ирене -

д-р психол. наук, профессор, директор, Австрийский институт интеллектуальных интеграций, Вена, Австрия;

аффилированный профессор,

Елабужский институт ФГАОУ ВО «Казанский (Приволжский) федеральный университет», Елабуга, Российская Федерация.

Ванчова Алица - д-р пед. наук, профессор, директор, Институт специальных педагогических исследований Университета имени Я.А. Коменского, Братислава, Словакия.

Ушакова Снежана Григорьевна магистрант, Елабужский институт ФГАОУ ВО «Казанский (Приволжский) федеральный университет»,

Елабуга, Российская Федерация.

\section{Авторсем суинчен пёлтерни}

Мерзон Елена Ефимовна - педагогика ӑслӑлӑхён к-чӗ, доцент, директор, АВ «Хусан (Атӑл с̧ум) федераци университечӗ» ФПАВУ Елабуга университечӗ,

Елабуга, Рас̧с̧ей Федерацийӗ.

Сибгатуллина-Денис Ирене - педагогика ӑслӑлӑхӗн д-рӗ, профессор, директор, Австрин интеллект интеграцийӗсен институчӗ, Вена, Австри;

хутшӑнса пулӑшакан професссор, AВ «Хусан (Атӑл суум) федераци университечӗ» ФПАВУ Елабуга университечӗ,

Елабуга, Рас̧с̧ей Федерацийӗ.

Ванчова Алица - педагогика ăслӑлӑхӗн д-рӗ, профессор, директор, Я.А. Коменский яче̌ллӗ университетӑн Педагогика енӗпе ятарлӑ тӗпчев ирттерекен институчӗ, Братислава, Словаки. Ушакова Снежана Григорьевна магистрант, АВ «Хусан (Атӑл с̧ум) федераци университече̌» ФПАВУ Елабуга университечӗ, Елабуга, Рас̧с̧ей Федерацийӗ.

Поступила в редакцию / Received / Редакцие с̧итнӗ 15.05.2021

Принята к публикации / Accepted / Пичетлеме йышӑннӑ 07.06.2021

Опубликована / Published / Пичетленсе тухнӑ 08.06.2021 